\title{
LANDSCAPE OF BRICOLAGE
}

\section{Spatial configurations and spatial practices at in-between territories in the Andes}

\author{
Autor: Monica Alexandra Rivera-Muñoz \\ Universidad a la que pertenece: University of Leuven - KU Leuven \\ Director de la tesis: Prof. Dr. Bruno De Meulder \\ Email: monicariveraec@hotmail.com
}

\section{RESUMEN}

El presente estudio indaga en la naturaleza de los paisajes intermedios de la ciudad de Cuenca, en Ecuador. Se trata del paisaje parte urbano y en parte rural que rodea a la ciudad. El trabajo apunta a un objetivo doble que se desarrolla en forma simultánea. Por una parte se trata de cualificar un territorio cuya dualidad como espacio urbano y rural es el origen de su difícil definición, y en consecuencia, de la poca atención que ha recibido tanto en los estudios urbanos como rurales. Por otra parte está la cuestión del "como" abordar, comprender y desdoblar el contenido y significado de las inherentes contradicciones de este territorio, y las lógicas de su desarrollo. La cartografía y el bricolage -como una herramienta conceptual-son empleados para abordar las intrincadas interacciones existentes entre el paisaje, sus actores, sus prácticas y la continua reproducción este paisaje.

Palabras clave: configuración espacial; prácticas espaciales, ensamble urbano; cartografía

\section{ABSTRACT}

This paper inquire into the nature of Cuenca's in-between landscapes -those "partly urban-partly rural" spaces next to the city-. The study has a double aim to be developed simultaneously. On one side it is the question of qualifying a territory whose duality as urban and rural, accounts for its indistinctness and the consequent little attention it has received by both urban and rural studies. On the other side is the question of "how" to approach such territory to truly grasp and unfold the meaning of its inherent contradictions, and the logics of its development. Spatial mapping and bricolage -as a conceptual tool-I are used to engage the intricate interactions between the landscape, its actors and their ways of producing this landscape.

Palabras clave: spatial configuration; spatial practices; urban bricolage; spatial mapping 


\section{INTRODUCTION}

\subsection{Preamble}

The Cathedral of Cuenca, in Ecuador, is a display of this territory's resources in general and of its marbles in particular. The assemblage at its entrance displays marbles from at least five different quarries, and it was conceived by Eloy Campos, a master marble mason who wanted to combine here the diversity that could be found in the Azuay province (Carpio, 1977, p. 67). The twelve columns that flank the main entrance are made of marble brought from three different quarries: for the shafts, marble from Checa; for the capitals and arches, marble from Sidcay; and for the base, marble from Sinincay. Campos was an experienced artist, and this was his master piece. He wanted to imprint Cuenca's most remarkable building with an own character expressed through the use of local materials, as if he was drawing a map of Cuenca's territory. However, Campos' harmonic map depicts not so much how Cuenca really is as much as it expresses city people's expectations of what the territory should be: articulated and coherent. Hence that the current picture of transformation of Cuenca's in-between landscapes those "partly urban-partly rural" spaces next to the city-are rejected and deemed as a downgrading of an imagined primeval and ideal state.
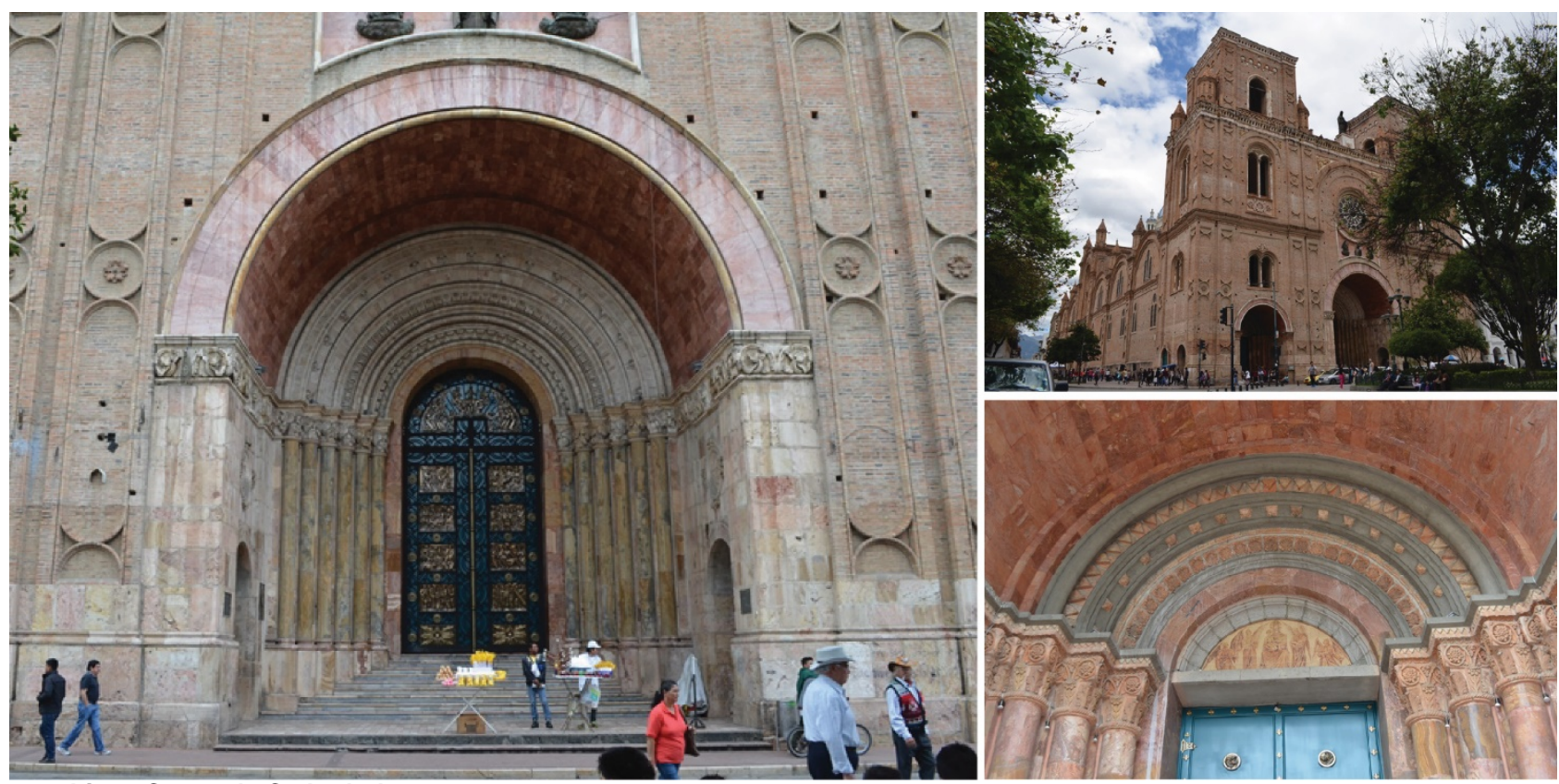

Graphic 1: Cuenca's Cathedral

(Rivera, 2017)

\subsection{Method and theoretical tools}

While the physical geography of Cuenca's in-between landscape is very distinctive, the elements that pertain its human geography like settlement patterns, economic activities, flows of people and resources, etc. are fine grained, and hinder the identification of clear figures. We are faced with a composite of heterogeneous and overlapping micro-landscapes, so fragile and rhizomatous that they rather may seem a jumble of residential, agricultural, commercial and manufacturing activities in conflict, than a system with any logic behind it.

The study has a double aim to be developed simultaneously. On one side it is the question of qualifying a territory where the confluence of urban and rural uses accounts for its indistinctness and consequently the little attention it has received by both urban and rural studies in the Andean context. On the other side is a question of method, "how" to approach such territory to truly grasp and unfold the meaning of its inherent contradictions, and the logics of its development. The question of the method is also one regarding the theoretical approach, because the latter 
becomes a tool -and tints any extra tool employed-; a lens to read and interpret the spatial phenomena that concern us.

A salient trait of in-between territories pertain their population's divergent 'ways of doing' from those of the dominant 'urban' culture. The conventional binary "city-countryside" approach cannot account for the complexity of the interrelations at play in the studied territory. A new approach is needed in order to characterize in-between landscapes for what they are, and not in function of the 'city' as a superior scale of reference, what reduces inbetween qualities to traits of an 'stage of evolution' towards a more 'urban' -superior- condition.

The number of people living in cities is often equated with the number of 'urban' people in a country, a simplification that reflects the dominance of the modern city image as a model of what 'the urban' looks like: modern, developed and dense. This identification singles out an only class of urban society, the capitalist city, ignoring "other forms of urban structure" and glossing over other characteristics of 'the urban' beyond the physical ones (Leeds, 1994), such as its territorial interconnectedness. The urban - Merrield points out, "is a more abstract and more concrete way to figure out the urbanization of the world, because it helps us think about a process that manifests itself in undergrowth as well as overgrowth, in abandonment as well as overcrowding, in underdevelopment as well as overdevelopment" (Merrifield, 2014, p. x). The term 'urban' -says Sanjek referring Leeds's formulation, "should stand for the interlocking of specialized localities (food-producing, mining, administrative, etc.), specialized technologies, and specialized institutions" (Sanjek, 1994). Hence that for Leeds what is urban is always a matter of degree:

“...degree of urbanness is measured not by the size of nucleations (which may be profoundly affected by ecology, institutional structures, and policies), nor by density (which may be profoundly affected by locality and technical specializations, as well as by policy), nor, generally, by the classical measures of "urbanization" effectively derived from recent Western experience, but, rather, by an interaction index of the three forms of specialization (to a large extent, these govern size and density)." (Leeds, 1994: 54)

In-between landscapes are therefore, part of a broader 'urban system' and its population should be deemed also as urban population of this system, since their sociocultural background and distinctness is not a factor of their 'urbanness'. While it is evident that concentration and densification of the processes of production are dominant of today's prevailing economic system, the precariousness of in-between landscapes -which irregularly alternates small nucleation and disperse occupation- cannot be simply considered as an intermediate stage towards an unequivocal densification. This is so, because in despite of the undeniable social homogenization that permeates every society today, the study case is still characterized by a population whose activities cannot only be explained in the base of economic stimulus, but in an important degree by non-economic ones, anchored mainly in tradition. Hybridity might be a better frame to understand the condition of in-between territories, a hybridity operated through bricolage practices of their population.

The weak presence of the government both, as infrastructure provider as much as regulatory body of spatial development in in-between territories, is counteracted by the varied and multi-scalar spatial practices that the population activate to transform and use their territory, and ultimately to make or complement their livelihoods. While people's practices may have a low impact in the landscape -if considered individually-, their replication and persistence over time, and the integration of new variables to the process of interplay between practices and landscape intensify their impact. The ancestral minga ${ }^{1}$ that has helped to get irrigation water for agriculture takes a new transformative power when it is activated to open a new road, implement potable water service, or built a new school; that is, extending the and attracting more urban fabric. The occupation of native forest for firewood and recollection of some food takes a new dimension when transnational remittances allow the opening of a road or the construction of a water reservoir, that diversifies as it intensifies the use of this fragile ecosystem.

\footnotetext{
${ }^{1}$ Collective and unpaid labor work done by the members of a community in the pursue of a common good
} 


\subsection{Bricolage as ways of operating}

Because of the multiplicity and the convergence of the practices operated in this landscape, I propose an image, the bricolage, as a conceptual figure to approach the understanding of both the landscape and the processes that bring it forth. The patchy pattern that results from mapping the layers of in-between territories can be compared with a work of bricolage (see figure 7), a construct made out of available bits a pieces and capable to evoke an image as much as a way of thinking and making (See: Levi-Strauss, 1962). The notion of 'bricolage' offers a parallel framework of thought to explore and interpret in-between landscapes. This is so, not so much because of the physical resemblances between the two 'products' -the landscape and the bricolage-, but more because of their processual nature and the way in which they display foremost the parts than the whole, delaying the understanding of their structure. Additionally, approaching in-between landscapes with 'bricolage' as a conceptual tool to cut through reality allows to engage the intricate interactions between the landscape, its actors and their ways of operating in and producing this landscape.

Bricolage is a piercing concept to approach, explore and represent spatial phenomena and the complex and multifarious processes and relations that render them (See: Mcfarlane, 2011; Rowe \& Koetter, 1978; Shane, 2005). As a construct made out of available bits and pieces, bricolage evokes and image as much as a way of thinking and making (See: Levi-Strauss, 1962). This is so, not so much because of the physical resemblances between the two 'products' -the landscape and the bricolage-, but more because of their processual nature and the way in which they display foremost the parts than the whole, delaying the understanding of their structure.

In popular and informal architecture, bricolage as the product of 'untamed thinking'2 has been celebrated for its resourcefulness and in their dimension as resistance actions and spaces against adversity (Real, 2008). Its nonlinear and open processes of transformation, reinvention, and continuous adjustment as ways to engage the world have served as conceptual models for some contemporary art practices ${ }^{3}$ (Dezeuze, 2008). The emphasis remains the process and the subversive nature of the practice.

De Certeau (1984) linked the notion of bricolage to people's 'ways of operating' or engaging in the most common activities of the everyday life ${ }^{4}$ (Dezeuze, 2008). While the everyday life seems to be cluttered of repetitive and irrelevant actions, it is their inertia what accounts for such practices recalcitrance and strength as 'ways of operating'. Such practices constitute a sort of hidden 'making' without a concrete product; a 'making' that "does not manifest itself through its own products, but rather through its ways of using the products imposed by a dominant economic order" (Certeau, 1984, p. xiii).

"Submissive, and even consenting to their subjection, the Indians nevertheless often made of the rituals, representations, and laws imposed on them something quite different from what their conquerors had in mind; they subverted them not by rejecting or altering them, but by using them with respect to ends and references foreign to the system they had no choice but to accept." (Certeau, 1984, p. xiii)

Bricolage as 'ways of operating' discloses the spatial agency of people's 'everyday creativity'. The variety of jobs that people perform to make their livelihoods, and the flexibility of displacement they demonstrate for performing them are essential qualities to peripheral population modes of knowing and doing, and as such, they are spatial and economic strategies with repercussions in the development of their landscape. An analogy can be drawn between the ways in which peripheral population -urban poor or peasant- make their livelihoods and shape their territory and the bricoleur of Levi Strauss:

The 'bricoleur' is adept at performing a large, number of diverse tasks; but, unlike the engineer, he does not subordinate each of them to the availability of raw materials and tools conceived and procured for the purpose of the project. His universe of-instruments is closed and the rules of his game are always to make

\footnotetext{
2 Dan Speber's term to translate the 'pensée sauvage' of Levi Strauss

${ }^{3}$ See the work of artist Marjetica Potrc

${ }^{4}$ De Certeau's study grew out of previous studies on marginal groups (Certeau, 1984, p. xii)
} 
do with 'whatever is at hand', that is to say with a set of tools and materials which is always finite and is also heterogeneous..."

(Levi-Strauss, 1962, p. 17)

\section{a. In-betweeness in the Paute River watershed}

The Paute river watershed is a territory configured by a constellation of minor and disperse settlements that complement and lean on Cuenca. This is a system of varied resources and skills, whose development dates back to pre-Hispanic times. Simultaneously, a hierarchical organization of space is at work, a colonial legacy that laid out a -still in force- double schema of geographically and ethnically uneven development between the city and the hinterland, between the white and the indigenous population.

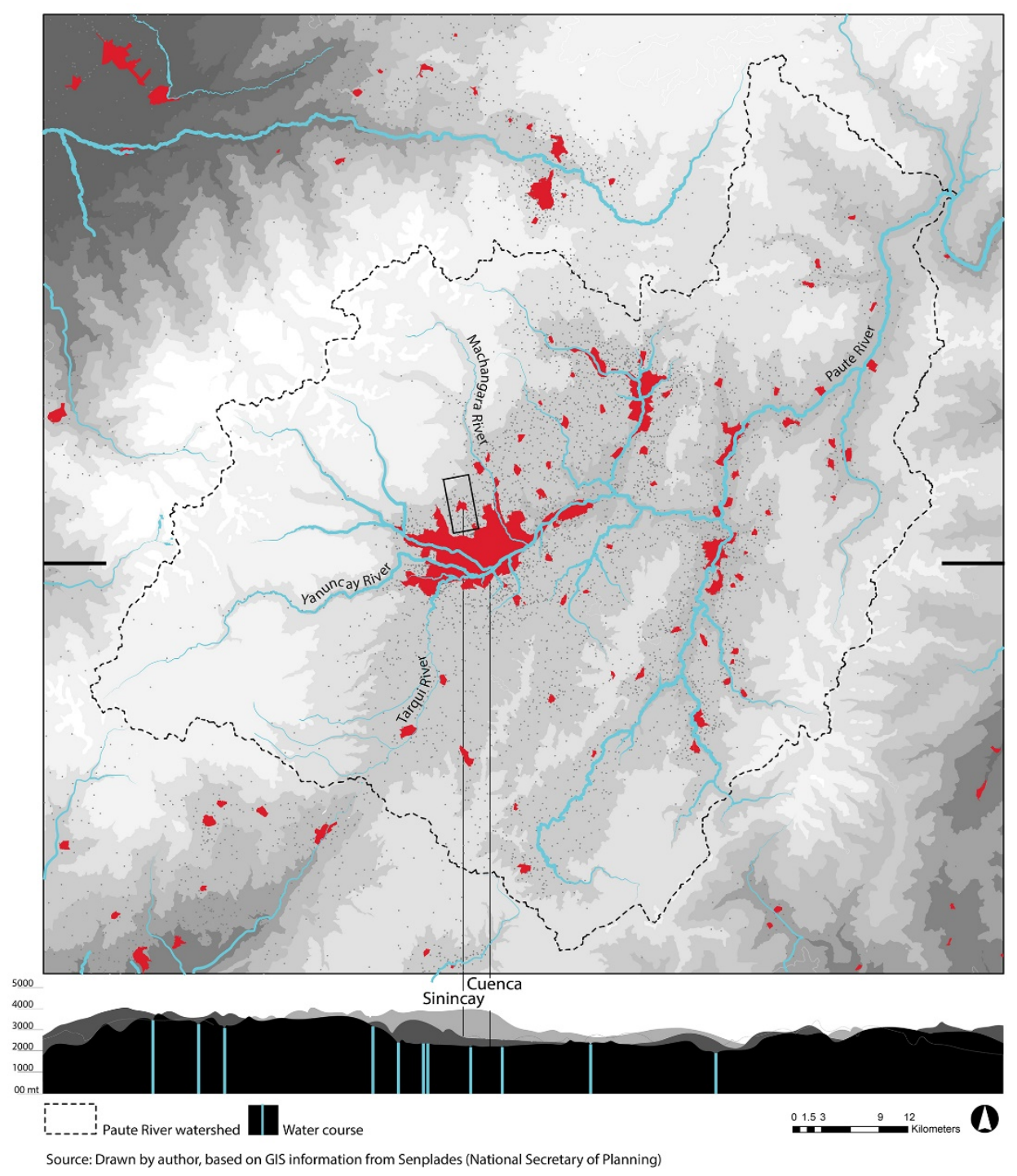

Graphic 2: Paute River watershed

Elaborated by author, 2017

Nonetheless core-periphery polarization is never absolute. Despite odds, 'peripheral' population is far from being a powerless segment. Instead, their dynamism is expressed by their territorial and global interactions; the social, 
economic and spatial strategies they activate to lever their social and economic movement; and very tangibly, by the patched texture of the in-between landscapes that they develop out of otherwise peripheral and subordinate territories. In-between territories developed out from a historic dialectic of the cultural and political imposition, struggle and adjustment -which characterized the colonial era and remained unchanged until mid-twentieth century- and also from a recent -and decisive- process of economic recalibration and cultural reinvention of peripheral population.

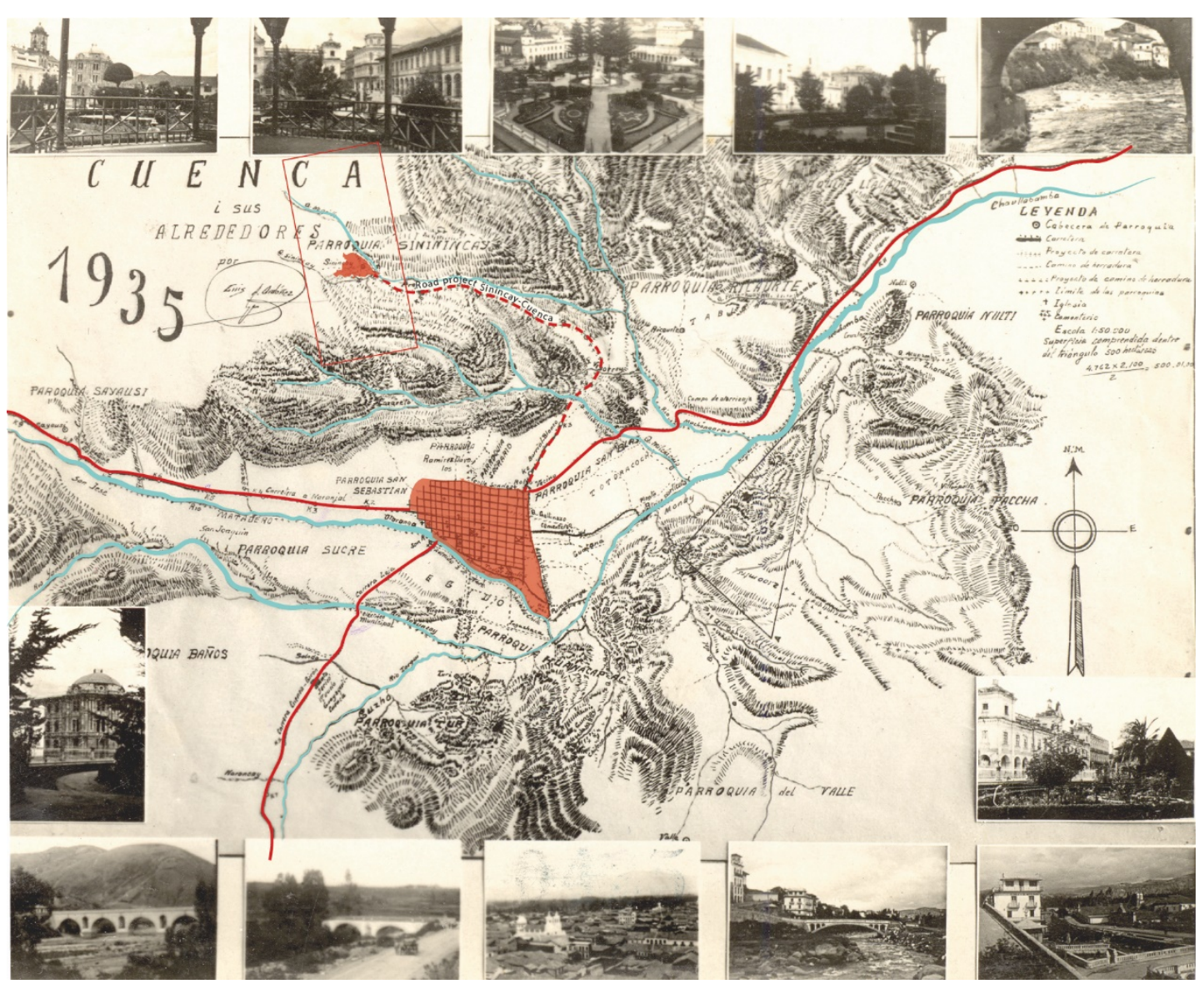

Graphic 3: Cuenca and its vicinity

Elaborated by author; base map by (Ordoñez, 1935)

Cuenca's in-between landscape is geographically as much as socially bounded. The particular geographic features of the region also play a role and give concreteness to the notion. In-between territory is located between the floodplain and the high mountains; between ease and harshness of inhabitation; between concentration and dispersion; between land as a consumer product and land as producer for life; between city and nature (Graphic 5).

Lastly, the notion of in-betweeness doesn't represent only an intermediate condition as much as one of a) indeterminacy (precariousness) and b) simultaneous coexistence of opposing conditions: the rural and the urban, the indigenous and the foreigner; the local and the global; the lacking and the abundant; the domesticated and the wild. 


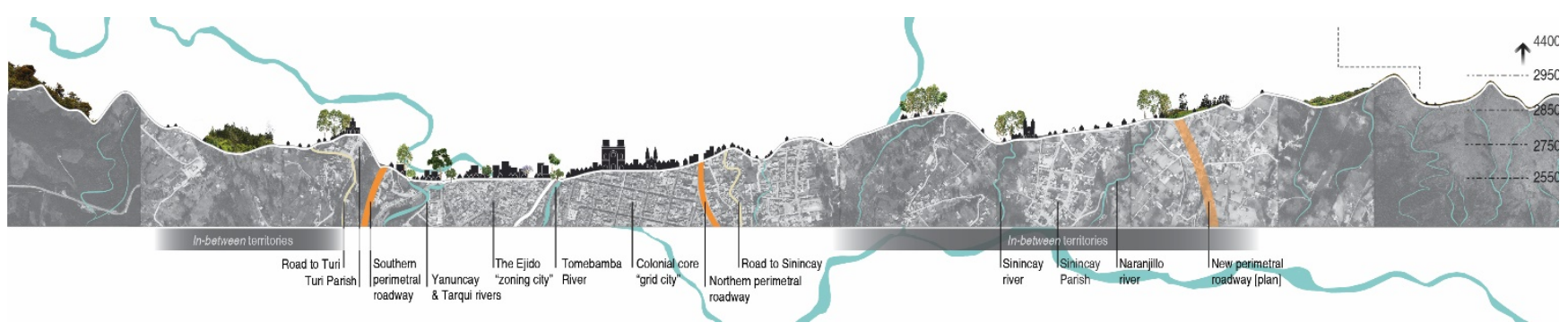

Graphic 4: North-South section through Cuenca's valley

Elaborated by author; base map by (Ordoñez, 1935)

\section{b. A brief historical glance towards Cuenca's in-between landscape}

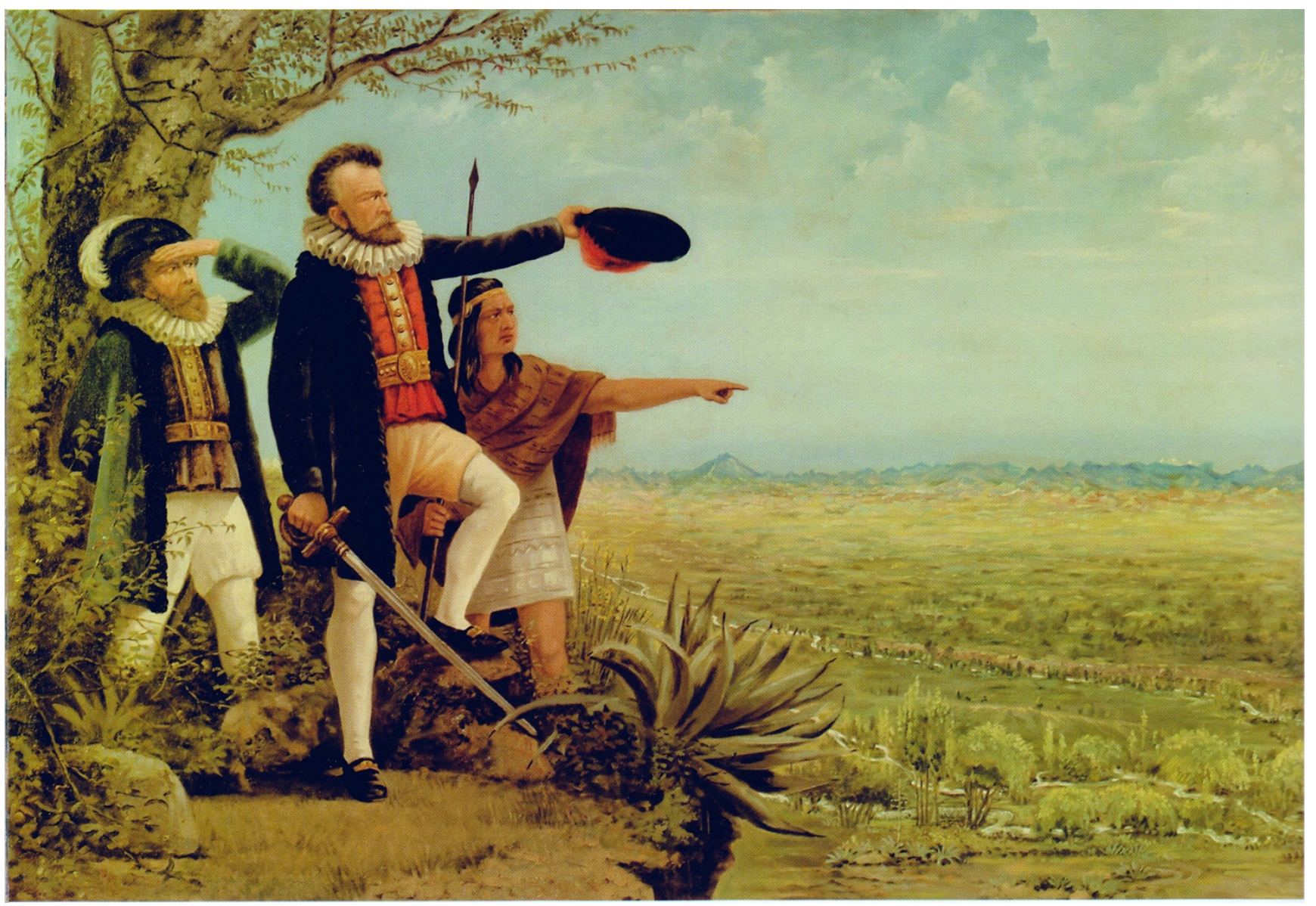

Graphic 5: Gil Ramirez Dávalos showing the place of Cuenca's foundation

Painting by Abraham Sarmiento, ca. 1910 in (Jaramillo, Martínez, Salazar, Abad, \& Aguilar, 2004)

The ethnical-based distribution of lands that followed Cuenca's foundation granted the flatter and most fertile lands to colonizers. Unequal power relations between indigenous and white population displaced the first -because official concession or illegal appropriation from the second- from their lands of ancestral occupation (PoloniSimard, 2006). Disposed from their ancestral lands, as if in a rebounding movement they shaped the new productive landscape in mountain slopes, where they cleared the forest for their crops (Chacón Zhapán, 1990:65). Indigenous society was land-based, then that land appropriation by the Spanish was profoundly destructive for 
their reciprocity-based societal organization. The production of new cultivation spaces in the mountains was their desperate attempt to preserve what they could of their autonomous way of living.

The interest in gold exploitation of nearby mines to Cuenca had brought Spanish colonizers to settle Cuenca already twenty years before its foundation in 1557. Soon it become evident that the expectations had been too high. The large number of people required for gold mining greatly reduced the real chances of its extraction and making fortunes out of it (Auncibay [1592], 1991, p. 538; Bello Gayoso [1582], 1991, p. 377). Only then the region leaned to the development of the region's agricultural potentialities oriented to the production for the regional market, which once again was based on the work of the indigenous population (Chacon et al., 1982; Chacón Zhapán, 1990; Espinoza, 1989; Poloni-Simard, 2006).

While indigenous population was not enslaved by the regime itself, the heavy tributes they had to pay forced them into a market of labor that exploited them, especially to those which by were trapped in servitude for generations, due to devious indebtedness with their landlords, and who were 'liberated' only after the agrarian reforms of 1964 and 1973. However, indigenous population was not a monolithic political segment, and others profited the fissures they found in the system and made their way into it by learning trades, becoming domestic workers, or through their periodic visits to the city for selling their products: corn, chicha ${ }^{5}$, firewood, etc. As they weaved personal and commercial networks with and within the city, they gained better spatial and political maneuver in the system, improved their economic condition and accessed the purchase of land, the center of their cultural and economic development, nonetheless they remained 'peripheral' in relation to the power classes which were white.

Over time an landowner-peasantry of indigenous and mestizo population emerged, whose cultural base remained grounded in agriculture, but whose always precarious economy incessantly increased the repertoire of possible activities. Simultaneously and most likely as a crisis-induced maneuver, population geographic span of action expanded as also did their connections, first with the city - since the early colonial times through wage labor and double residency, or through artisanal home work like textiles weaving and elaboration of toquilla hats-, then with the coast of the country - since late XIX century through seasonal and permanent labor migration to exportoriented plantations- and finally at international scale -since the last third XX century through transnational emigration-.

\footnotetext{
${ }^{5} \mathrm{~A}$ fermented beverage made of corn.
} 


\section{SININCAY: BRICOLAGE THROUGH THREE NARRATIVES}

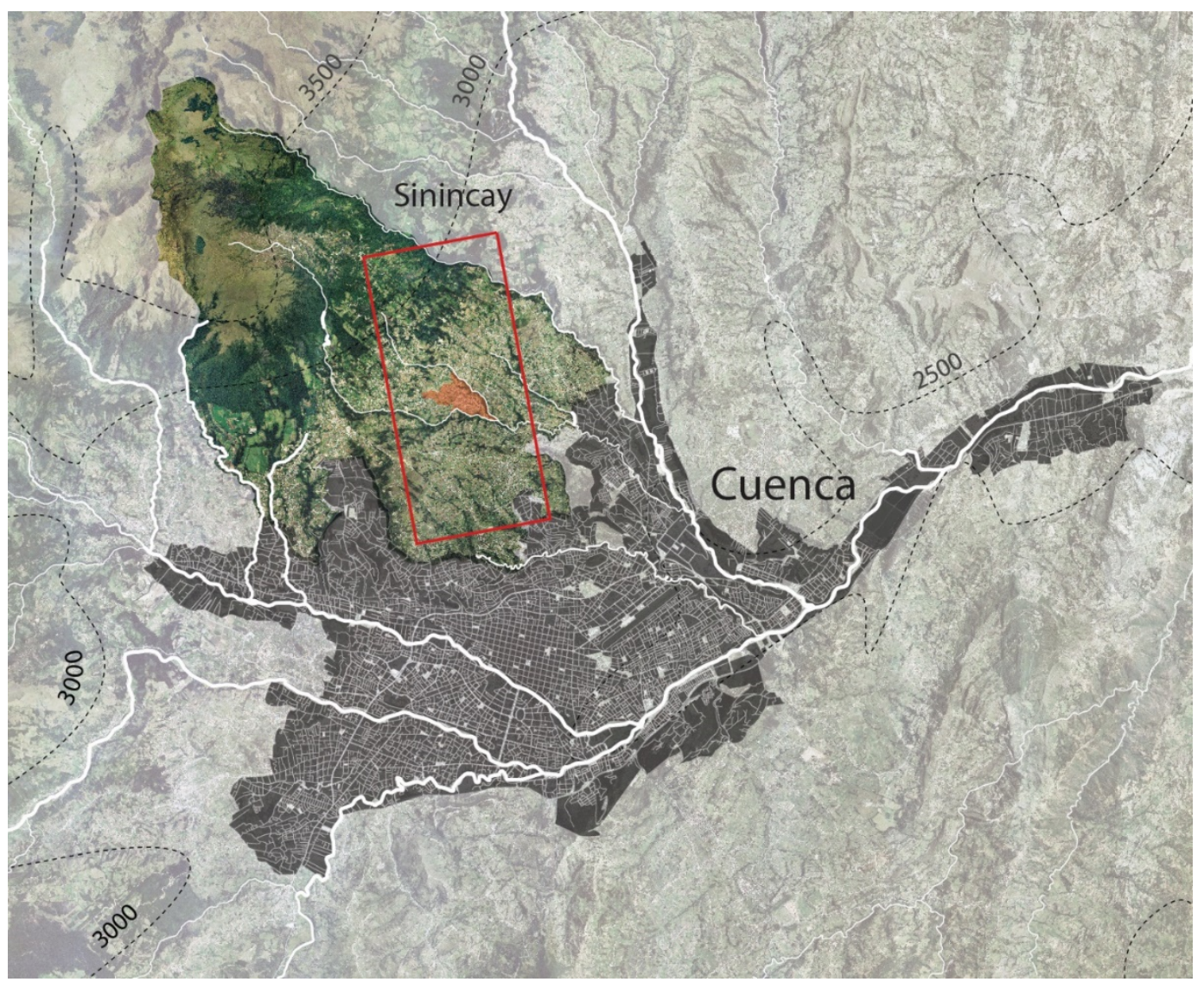

Graphic 6: Sinincay Parish location in relation to Cuenca Elaborated by author, 2017

The patchy figure resulting from mapping Sinincay's land uses underscores its essence as an in-between landscape (See Graphic 7). It encompasses a wide variety of land covers and uses that include moorland, native forest, agriculture, residential and manufacturing uses. Mapping at a closer scale shows that regardless of the distinct topography and available resources; and the consequent varied activities performed by their inhabitants, the pattern of occupation continues to render kaleidoscopic. Forged out of need and resourcefulness, Sinincay's landscape is strongly correlated to the ways in which its population engage what they know -tradition, trades, social practices, etc.- and what they claim a right to -land, natural resources, transnational remittances, the built fabric, infrastructure, etc.- in order to make their livelihoods.

The following narratives are tightly intermingled. They share a common socio-spatial structure where land attachment and gained property rights -either claimed or bought- are at its basis. They also share characteristics like the prevalence of smallholdings as the dominant form of land property and their belonging mostly to a mestizo peasantry of indigenous base. The well-known low economic stability of these groups makes them highly vulnerable to the ups and downs of the national economy ${ }^{6}$. However their condition as landholders opened for them -more than thirty years ago- the door to transnational migration, and more recently the possibility of indebtedness which they are using for undertaking or fortifying their economic ventures.

\footnotetext{
${ }^{6}$ The index of full employment of urban population doubles the one of rural population (50\% versus 23\%). Accordingly, the total of underemployment, unpaid job and other forms of insufficient employment sums up $75 \%$ in the rural areas versus $43 \%$ in the cities (Instituto Nacional de Estadisticas y Censos INEC, 2016)
} 


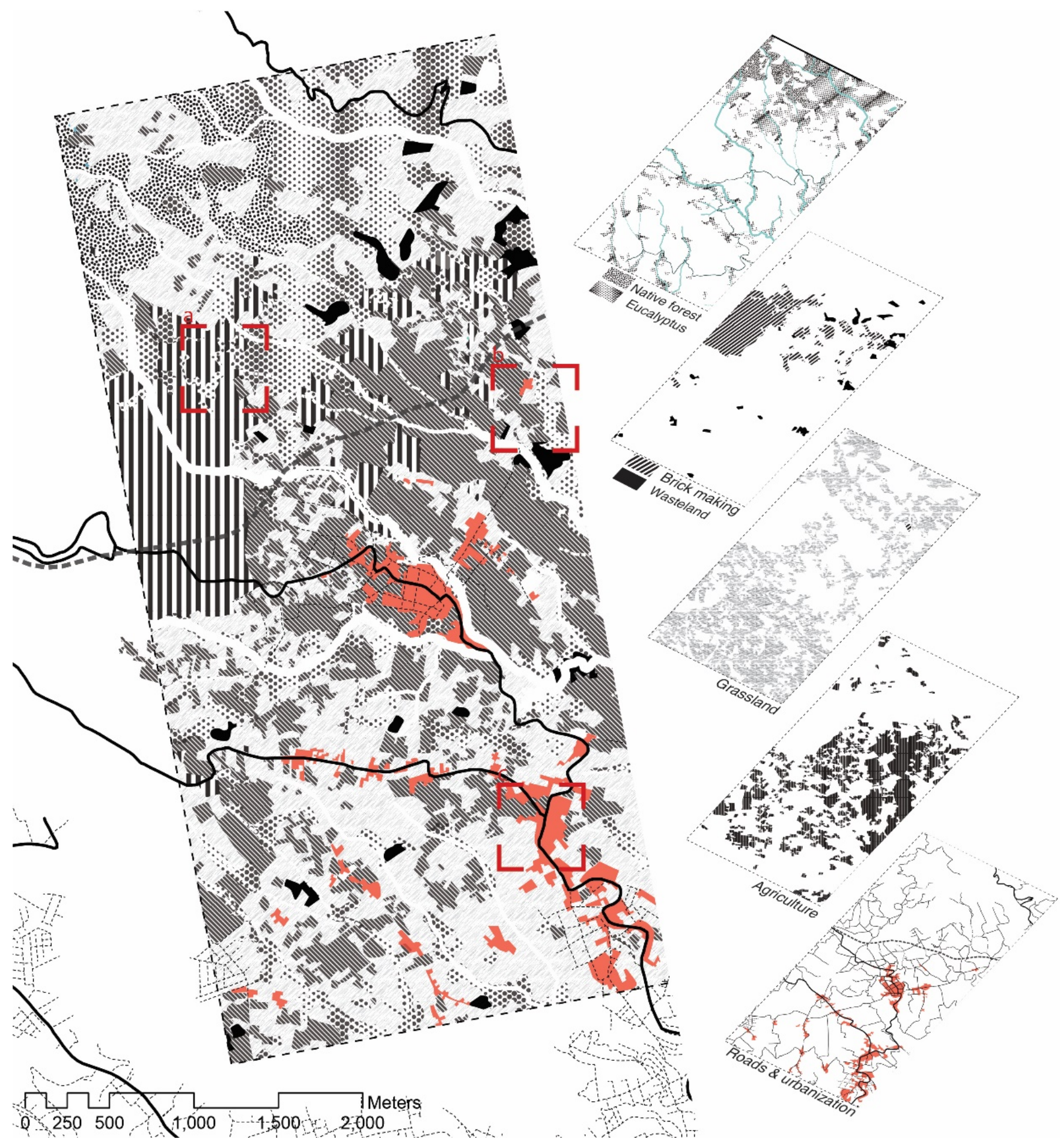

Graphic 7: Sinincay landscape of Bricolage

Elaborated by author, 2017 


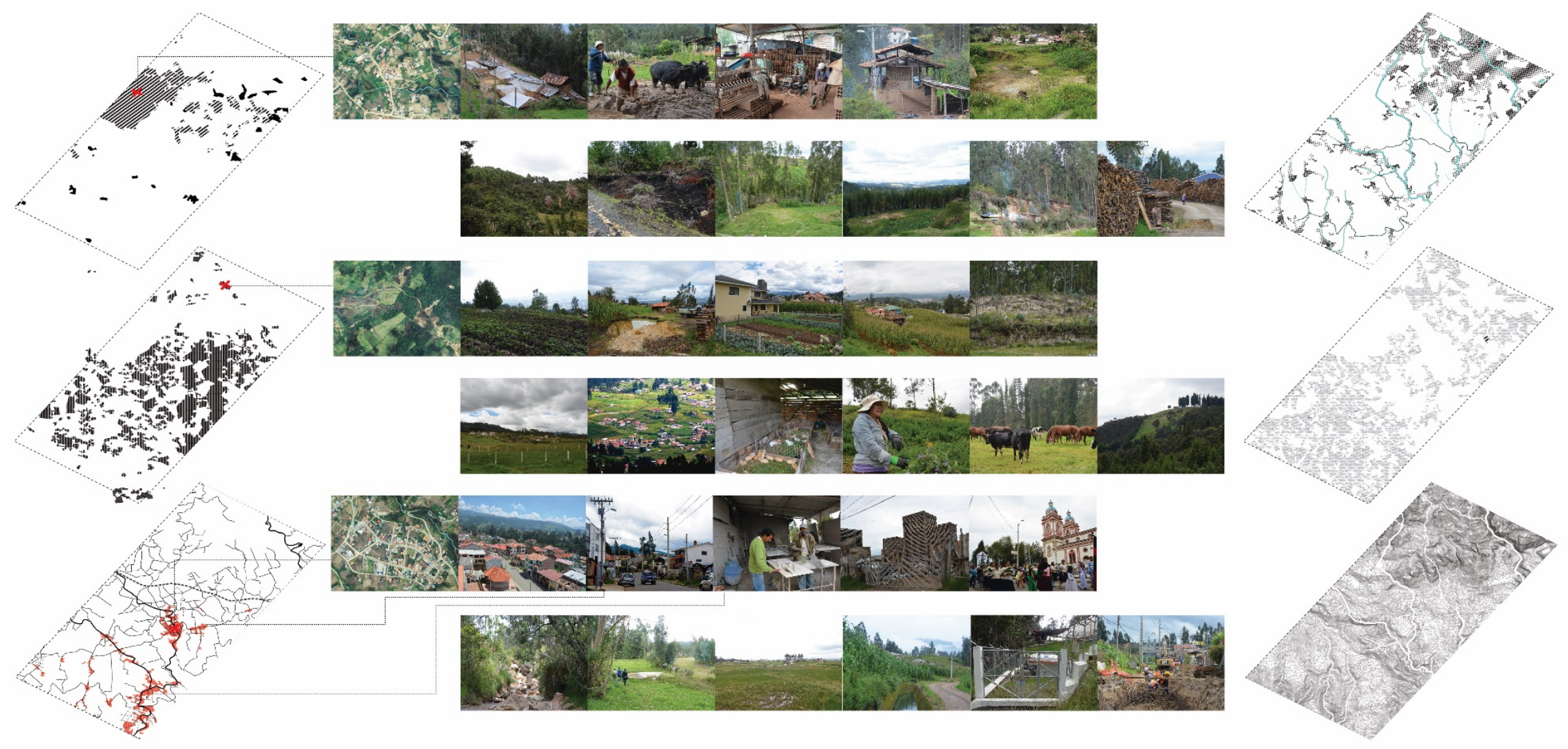

Graphic 8: Sinincay landscape layers Elaborated by author, 2017 


\section{a. El Salado: Land, patrimony and incremental urbanization}

Sinincay terrain is characterized by the frequent alternation between convex and concave slopes, with abrupt slope changes and ravines in the water courses, consequently, land suitable for settlements or agriculture is rather limited. Then that the characteristic disperse settlement is not a uniform pattern, but it presents a relative clustering happening mainly in the convex hills of low gradient, and linear settlement along main roads, with frequent interruptions due to geographical and topographical features. In general, slopes and flatlands -with the exception of parish centers- present a diverse spatial development, driven not only by their geomorphological characteristics.

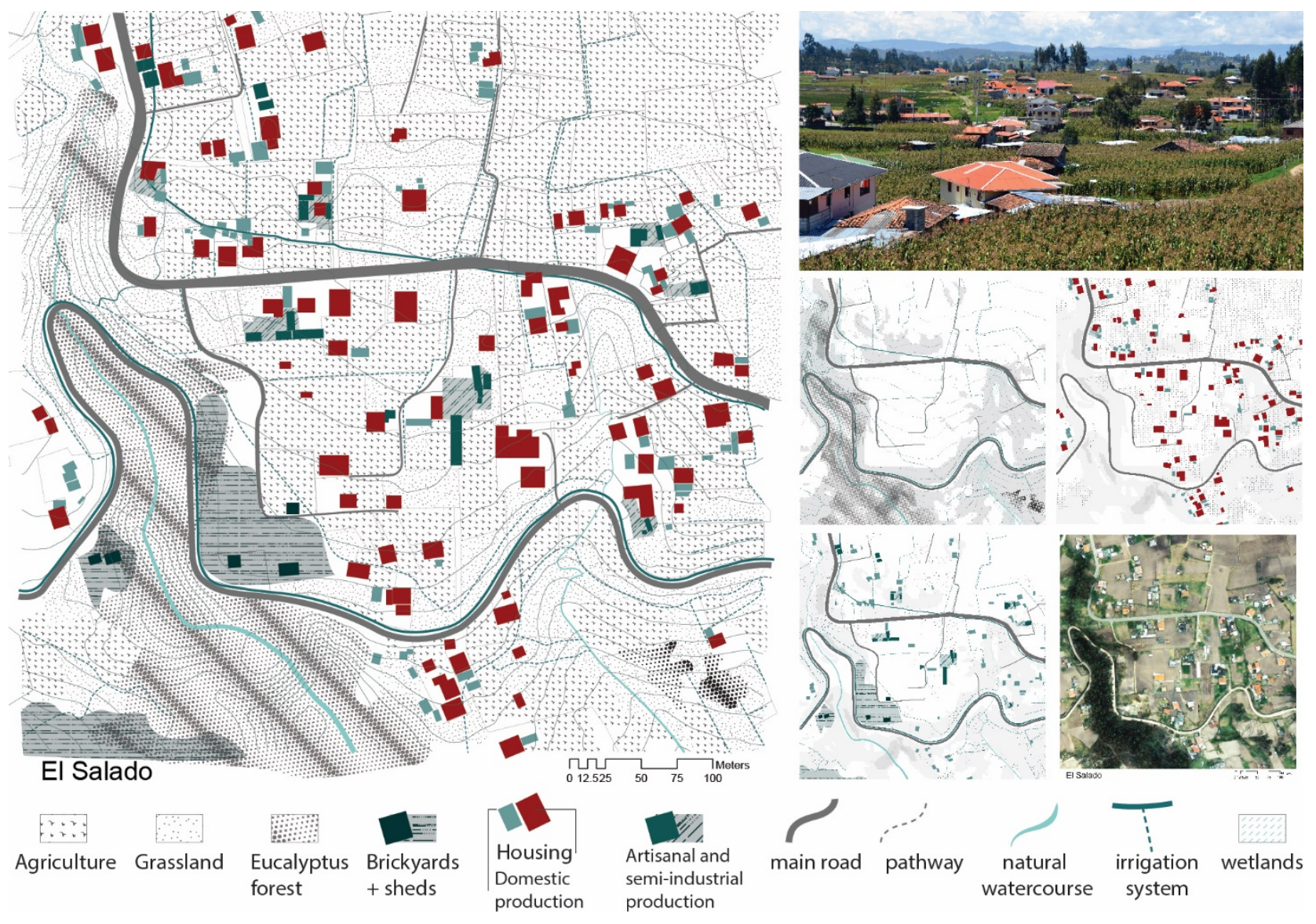

Graphic 9: El Salado

Elaborated by author, 2017

Due to the historical process of land allocation, lands with the most advantageous topography and fertile soils were part of large scale properties, and were usually dedicated to pastures and cattle, while the mountainsides were given for indigenous use and over time become intensely subdivided and cultivated. This correspondence between land size, location and land use was still observed in the Ecuadorian highlands by Saunders (1961) before the first Agrarian reform? ${ }^{7}$. This relation -though in medium sized properties- is evident in several locations around Cuenca city: to the northeastern part of Sinincay; towards Chiquintad, along the Machangara river

\footnotetext{
${ }^{7}$ Based on the first Agrarian census of 1954, Saunders points to the relation between the size of the landholdings and the land use; and how the prevalent location of each class contributes to the severe soil erosion that was visible in the highlands: "In the highlands, 93.8 per cent of the area of properties of 2500 hectares or more is devoted to pasture and only 3.1 per cent to cultivation. On the other hand, properties of less than one hectare in the highlands have 90.8 per cent of their area devoted to cultivation and 5.9 per cent in pasture" (Saunders, 1961 , p. $60)$.
} 
floodplain; to the east of the city, along the Cuenca river8; and to the south along the Tarqui river. Large and medium landholders were usually urban people of medium and high economic strata, who had low economic dependence on such activities, then that their properties had for their families more social and political connotations than economic ones. The agrarian reforms of 1964 and 1973 abolished the huasipungo ${ }^{9}$ and debt peonage, and enforced the handover of land ownership to huasipungo-engaged workers. Restrictions regarding maximum extensions for estates -introduced by the agrarian reforms- and the reduced availability of peasant labor force triggered the subdivision and sale of large properties, making land available for purchase by landless indigenous population for whom this was a long and deep yearning. Steep and less productive land was sold first, while the rest was reserved as accumulation assets for their owners. As the city grows and land becomes expensive in the most central areas, these 'reserves' of flat and fertile land are progressively urbanized and released into a voracious market of land which spreads the city, piecemeal consuming all the flatland in the Cuenca Valley.

The land of the peasants follows a different trajectory that the one with urban owners. Peasant's landholdings are prone to 'incremental urbanization' due to the well-established custom between peasant population of subdividing and giving a piece of land to married children for their house construction, a process successively repeated. For peasant population land is part of their family patrimony, a legacy of economic as much as cultural significance.

Both modes of development generates disperse patterns of urbanization, however they are distinct. The difference arises from two different understandings of land: as patrimony ${ }^{10}$ or as a capital, ultimately with different connotations for the social body that inhabits them. The first is a process carried out between family, and the handing over of land is a sort of ritual that renews their solidarity and reciprocity ties. The second is a commercial transaction between strangers which doesn't entail any obligation after its completion. Two distinct spatial developments stem from this initial condition. The first tends to make use of existing infrastructure -often based on community work-, what often entails further rights and obligations to be personally fulfilled. The other resembles more the production process of a consumption good -making new all what is needed, in this case, all to 'connect' itself to the broader city system-, based only on money availability and conveniently anonymous. Over time the first mode of development tends to increase its density by further property subdivision; the other keeps on taking new land every time.

\section{b. El Cruce del Carmen: culture, roads and space development}

Sinincay develops as a system of 45 communities, politically and administratively organized around the parish centre. A community constitution is traditionally the result of spontaneous processes of self-identification, although more recently they also emerge through more planned processes and in an attempt for gaining visibility before local authorities. The existence of a community doesn't suppose equally the existence of a settlement concentration, rather, occasional congregation is enough to hold them together -most commonly driven by religious reasons. Over time social links are strengthened in the pursuit of a common objectives, like the opening of a road or the establishment of a school.

During the 1960's people from the lower part of Sinincay organized themselves to get built the road that connected Sinincay with Cuenca, via Miraflores. As community leaders, local artisans organized mingas ${ }^{11}$ and lead the negotiation process with those whose lands would be crossed by the new road. While the new road remained precarious, it changed the dynamics of the settlements to the south of the parish centre, triggering the emergence of new communities among them El Cruce del Carmen. El Cruce emerged at crossroads of the new CuencaSinincay road and the way to El Carmen, a much older community located towards the old Cuenca-Sinincay road.

\footnotetext{
${ }^{8}$ This particular floodplain is under a rapid process of urbanization which was triggered by the Cuenca-Azoguez roadway construction in 1995. ${ }^{9}$ Huasipungo was a parcel of land given by a landowner to a worker in exchange for days of free farm work. The huasipungo in combination with other forms of indebteness devised by landowners, kept many indigenous people under servitude in the haciendas until the agrarian reforms. The 1964 reform abolished the huasipungo, until then the main 'capture' device and enforced the handover of property rights to workers.

${ }^{10}$ Zouain (2005) traces back the origins of the concept "patrimonium" to the ancient Greece: ".. it represented the land, the estate that produced the family's basic commodities. It could neither be traded nor sold: it was to be transmittetd from one generation to the next".

${ }^{11}$ Collective and unpaid labor work done by the members of a community in the pursue of a common good.
} 
Public transport was available since 1967, however, it was only after the widening of the road in the 1980's that bus frequency increased and El Cruce concentrated population and built fabric.

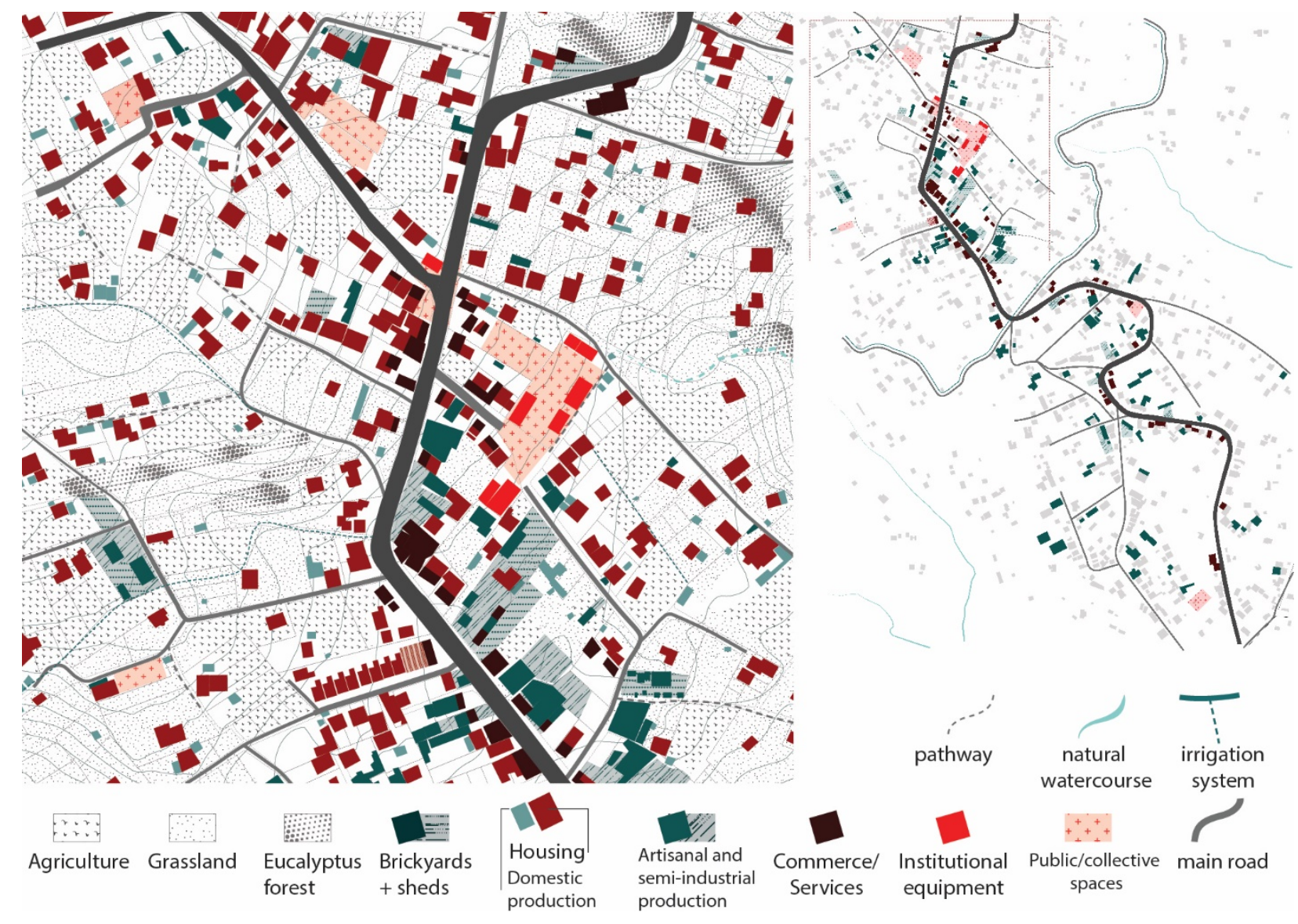

Graphic 10: El Cruce de El Carmen

Elaborated by author, 2017

In El Cruce, church and school were the result of communal efforts, and as such they hold symbolic importance for their population. Their cohesive power makes spin around them the centre of meaningfulness of the new community.

Frequently seen in the Andean rural context, an essential action of the emerging community is twofold: on one side is the spatial designation of a formal core, on the other is participation -as an act of commitment- through minga for the construction of the communal house and/or a shrine. The designation of a centre can be a very long process, which demands strong leadership and negotiation capacities from its leaders, since it usually involves being able to get personal and financial commitment from the community. The analysis of aerial photography of relatively new communities in the periurban area of Cuenca shows that the selection of the site strategically chosen in the convergence of several large landholdings. Generosity and commitment from its owners to the emerging community are then tested. If the donation of a plot of land is not possible -for the plaza, the school or the shrine, the rest of the community will have to support the purchase.

Bottom-up constituted, the community centre becomes a truly 'symbolic intermediary', an instrument of communication (Shane, 2005) and ultimately of construction of an new 'enclave'. Like the city, the territory develops as a 'system of fragmentary enclaves', similarly to the way that Rowe and Koeter saw the city, 'small utopias each with its own self-organizing system of order" (Shane, 2005, p. 130). 


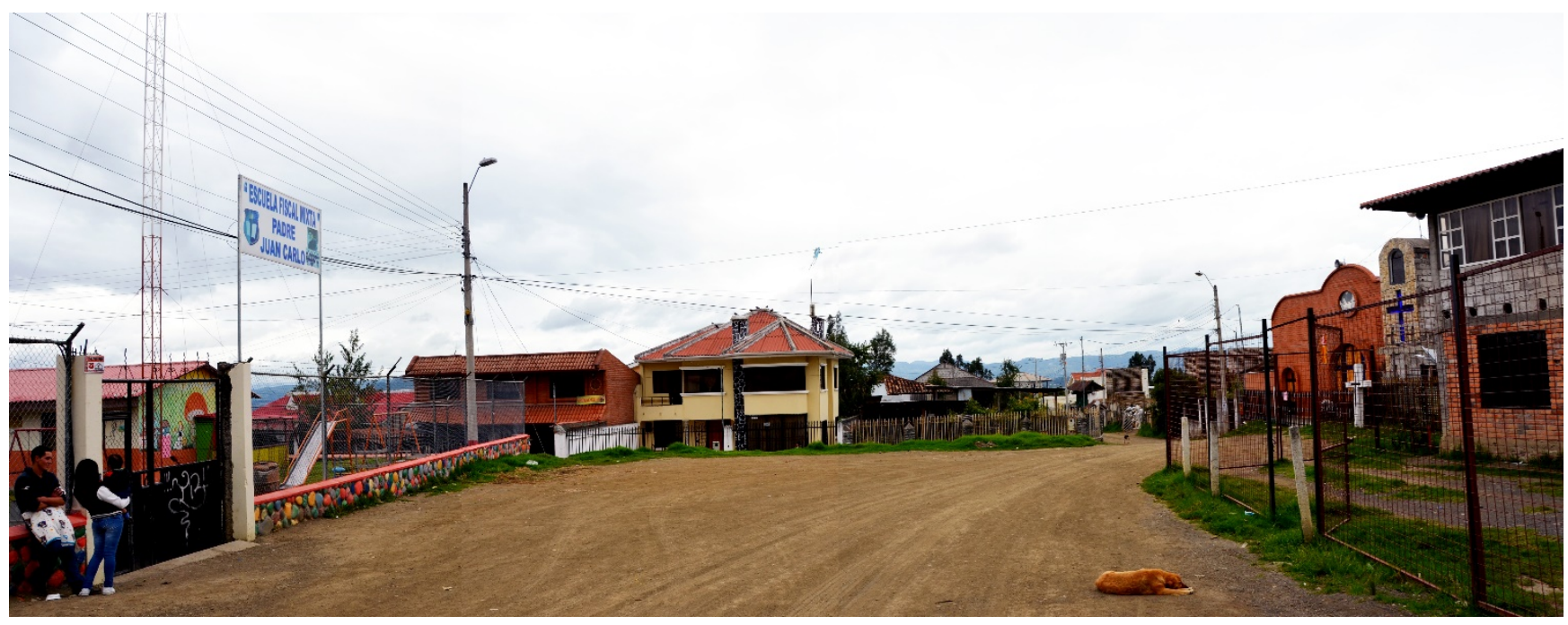

Graphic 11: El Cruce de El Carmen

Elaborated by author, 2017

In the parishes around Cuenca we can observe that the lack of planned public spaces is counteracted with the emergence of spaces of diverse type and size which acquire the character of collective -the communal house, the grocery shop, and very importantly, volleyball courts, by far, the most animated spaces of all.

Roads, as routes of access and connection between parish and city play a fundamental role for the parishes. They frequently work as an axis of spatial development and concentration, like in El Cruce, where commercial and manufacturing activities locate preferentially along its main road. Over time El Cruce is intensifying its building fabric, diversifying land uses, concentrating functions, and in general increasing its overall complexity.

The long tradition of construction-related trades existing in the parish is now continued and accentuated by the presence of related productions in carpentry, metallurgy, granite works and stucco sheets, which profits from the relative availability of trained workforce. Further, new trades learned in the city are also reproduced here -bakery and pastry, automotive collision repair and painting, mechanic and car repair, steel and aluminium carpentry, among others. With a milder topography than lands closer to Cuenca, the simultaneous requirement for space and connectivity of industrial productions are meet in this territory. While some former city-based factories buy or rent land to establish their production plants in Sinincay because the relatively low cost of land, they are still familybased and small-scale factories.

The urbanization of this enclave has gained visibility for its community, with positive economic implications specially for those manufacturing. The relative concentration of small manufacturing shops in El Cruce gives them all a visibility and a fame that they wouldn't otherwise have, gaining exposure to city clients from their own places. Clinching in their gained knowledge on trades and built connections, and profiting from landownership, El Cruce -the same happens with other trades in other locations in Sinincay- is currently a well-recognized place to find furniture -wholesale and retail sale- or where to hire people to do carpentry or metal work for a building house.

\section{c. Sigcho: Resources and resourcefulness}

The territory of those Cuenca's parishes adjoining the city encompasses a variety of development conditions which in general terms can be described as a progression from the city to nature, from the flat to the sheer terrain, from the constrained to the unbound. However, forms of habitation should not be simplified in the same manner. While urbanization may be rendering in-between territories more urban, and people everyday habits may becoming more sophisticated, other traditional practices endure and continue to entrench in the interplay between their traditional skills and the resources they have access to -even when such activities are no longer crucial as income for their 
households-. Further, resources deriving from employment in the city or transnational migration are frequently invested in fueling in-situ family undertakings aimed to build up their economic autonomy.

Patricio, a brick maker in one of Sinincay's surrounding communities, worked during eight years in the United States. Along those years he supported his sister's university studies, bought machinery for making bricks, and built his house in the centre of the Parish, where currently he also rents two commercial shops. His personal assets and activities intermingles with those of his relatives. In partnership with his brother, they installed a brick factory in a family plot that they terraced and made improvements. Patricio has also a truck that he uses to carry the vegetables that his mother produces, and that he sells in a coastal town. In his return trip, he brings compost for his mother's crops or corn for the elaboration of animal food, which his sister elaborates. Remittances and the investments emigrants do increase the economic opportunities for he extended family, and also strengthens the ties between them. Furthermore, emigrants' real estate investments especially when these are done in the parish centres, indirectly contribute to their towns enlivenment by providing affordable rental units for housing and commerce, which appeals to potential new dwellers.

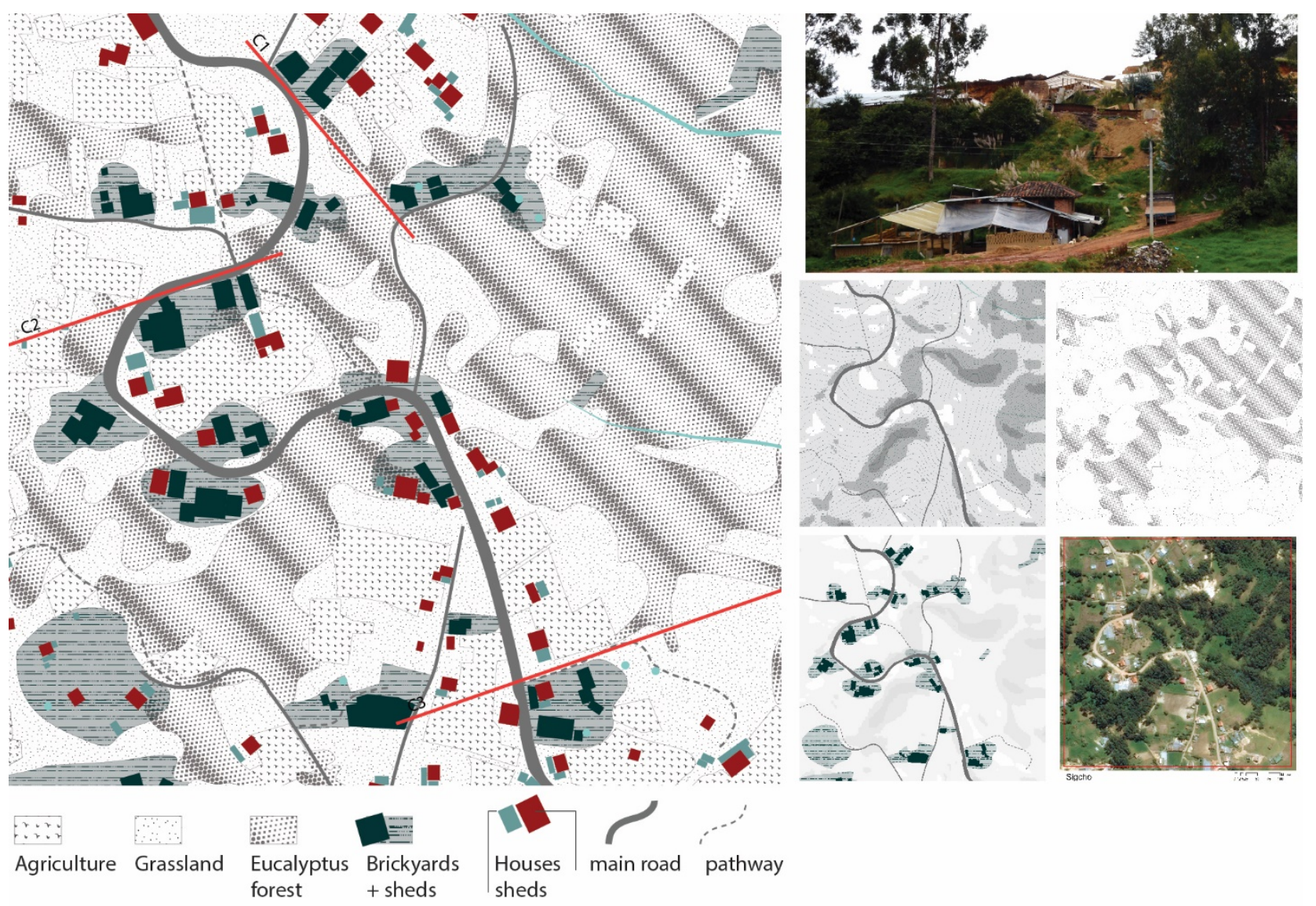

Graphic 12: Sigcho

Elaborated by author, 2017

Sigcho is the highest inhabited location of Sinincay at almost 3000 m.a.s.l. Its spatial development depicts the economic interplay between soil -rich in clays and limestones-, topography, and roads. The area is also characterized by a rough topography mainly covered by eucalyptus which alternate with numerous brickyards and spaces of domestic agriculture in the less steep areas. As clay pits exhaust in lower locations, roads prolong and new pits are opened every time in higher locations, clearing native forest and expanding the agricultural frontier.

Brick production in Sinincay is mostly a small scale and family-based enterprise. Hence, a new brickyard most frequently implies also the establishment of farm lands, tree planting, and eventually the substitution of the firsts 
makeshift quality shacks by permanent dwellings within the same plot, opening a new line of settlement that follows the road, a road that follows resources, or rather that makes them available by piercing their borders.

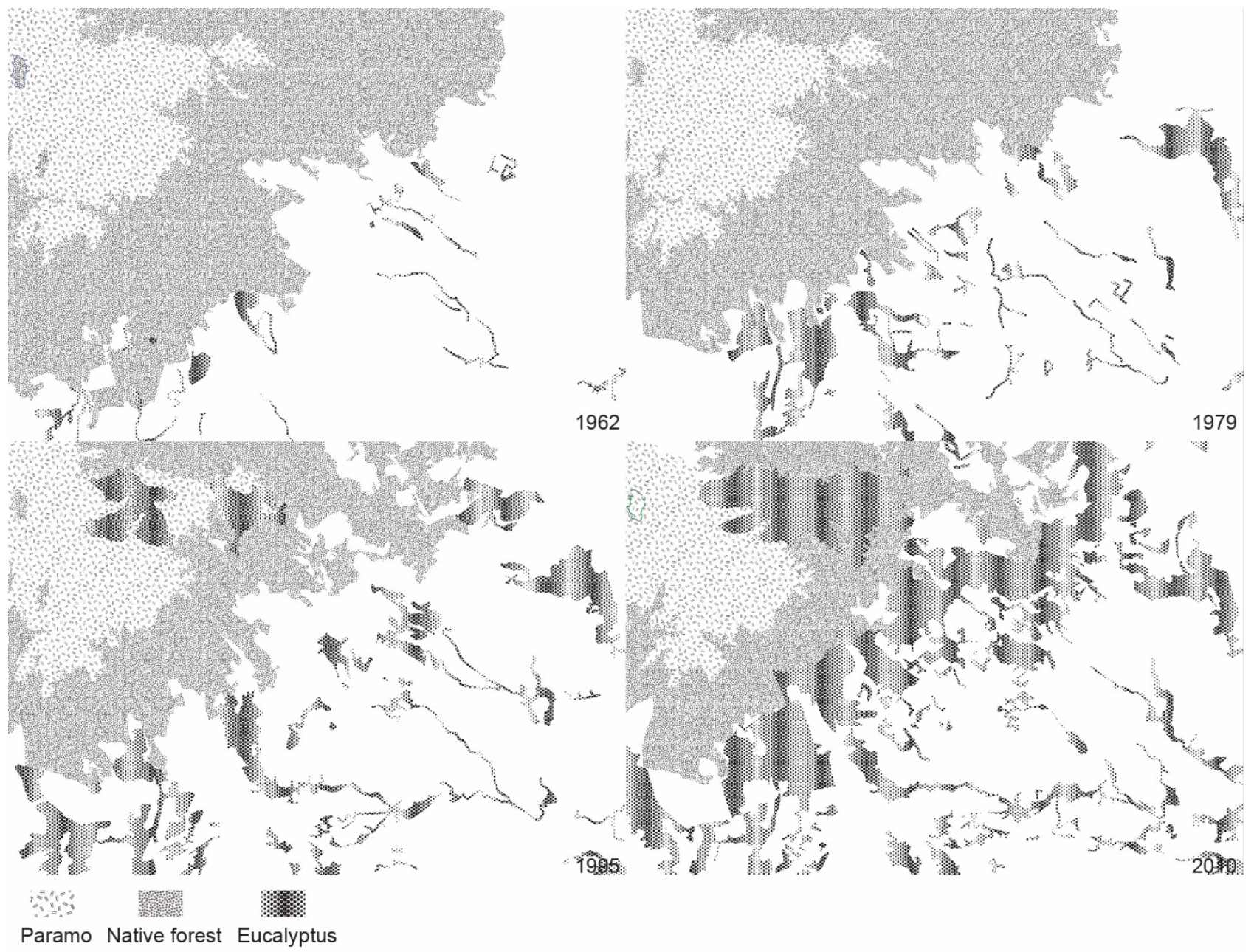

Graphic 13: Progression of forest transition

Elaborated by author, 2017

Growing inhabitation of highlands has an evident impact in the land cover change of native forest and even paramo ${ }^{12}$ vegetation. A pattern of land cover and soil transformation can be identified. It starts with the clearing of native forest for the use of the rich and fertile soils covered by them. High slopes and abundance of water on one side, and lack of land and water management on the other erodes the land, which soon decreases in productivity. Land cover then shifts to grass, very commonly to kikuyu, a very strong and invasive type of grass. If erosion is stronger than no organic material is left, trees are planted as an erosion control and land stabilization measure. Because of its fast growth and economic value, eucalyptus is the specie most commonly used. Eucalyptus planting extends to slopes and steep banks of watercourses as a way of making productive difficult lands which otherwise would be considered useless.

The use of Eucalyptus is problematic because in the long run, it dries further the soil and watercourses, while simultaneously it weakens any neighboring native forest. However, at the same, cultivated forests are economically important for the population, since they are renewable resources which basically don't demand

${ }^{12}$ The high altitude montane ecosystem that can be found in the Andes over the 3.000 m.a.s.I. 
further investment or labor after being planted, all since they are frequently sold as standing forests for their harvesting and processing.

While some brickyards continue activity even after clay have exhausted from in-site pits, others cannot afford buying clay off-site, especially those households still operating only under artisanal methods. Impoverished by the low profitability of having to compete with the prices of those who have mechanized their processes, they abandon brickmaking as their own business and sell their workforce as day workers to other producers or in agriculture. Those owning more clay mines will move their activities to the new spot in the mountain. The outcome is the same, lack of post-extraction management either for mines or for brickyards results in the emergence of a scattered landscape of wasteland as by-product, and the claiming of more native forest and land for production.

\section{FINAL REMARKS: BRICOLAGE, INERTIA AND AGENCY}

The exposed narratives touches on different subjects, which in varying degrees are present in each case. Passing from the broader to the smaller scale, they highlight how people engage in the making of their places.

Two opposite and complementary characteristics -the wide diversity of activities performed and the predominant small scale of their development- appears as inherent to this landscape. The frequent fusion between the domestic and the productive in their households, commonly acquires the form of cluttered assemblages that mirror in the domestic micro-scale the qualities seen at the broader landscape scale at in-between territories. The permanent 'provisional' character of in-between landscapes derives and feed backs the sort of 'dialogue' between their bricoleur ${ }^{13}$ minded population and the diverse but limited and closed universe of possible elements they can recourse to. The closed universe of 'tools and materials' is nonetheless contrasted by the wideness in their usage and adaptation to the tasks at hand: the old roof zinc sheets are now the enclosure for the coops; the clay mixer bought for modernizing the family-run brick factory becomes an extra source of income by providing mixing service to neighbouring factories. The tasks are always open-ended, the buildings always ready to receive an extension, an adjustment, a change of use, one more fix. What for a urbanite -comfortable with the consumerist cycles of use and fast disposal- is waste, for the in-between dweller is material to be held 'just in case' for a future use.

Bricolage as a spatial practice and product discloses 'inertia' and 'agency' as two opposed but complementary modes of people's 'ways of operating" in the studied context. As modes of inertia, the persistence of form in land property, endurance of social practices, as well as peasant's strong attachment to land are at the base of the spatial development of in-between landscapes. Gripped and interplaying with them, people nests varied ways of agency that work at different speeds and rhythms, and involves individual as well as collective modes of making. Working at various combinations, their many activities -the continuation of agricultural practices and artisanal manufacturing; the engagement in waged work in the city; the beginning of a business venture in the family property; or the risky pawning of lands to emigrate abroad-interplay with social practices of cooperation, unfolding landscape transformation. While the notions of inertia and agency insinuate themselves as opposite forces, in the socio-spatial interplay they work as complementary. It is in the slowness and perceived security of inertia -read traditional social and spatial practices- that population agency nests and translates in the plural and unbound manner that people engage the use of their resources -in and off-site-, and the occupation of their territory.

\section{REFERENCES}

Auncibay [1592], F. (1991). Relación del sitio del cerro de Azruma y distancia de leguas a Quito, Loja y Cuenca y repartimientos de indios de aquella provincia. In P. Ponce (Ed.), Relaciones histórico-geográficas de la Audiencia de Quito: s. XVI-XIX (pp. 532-545). Madrid: Consejo Superior de Investigaciones Científicas, Centro de Estudios Históricos, Departamento de Historia de América.

Bello Gayoso [1582], A. (1991). Relación que envió a mandar su majestad se hiciese de esta ciudad de cuenca y de toda su provincia. In P. Ponce (Ed.), Relaciones histórico-geográficas de la Audiencia de Quito: s. XVI-

\footnotetext{
${ }^{13} \mathrm{~A}$ kind of tinker
} 
XIX (pp. 372-412). Madrid: Consejo Superior de Investigaciones Científicas, Centro de Estudios Históricos, Departamento de Historia de América.

Carpio, M. (1977). La Catedral de la Inmaculada de Cuenca. Thesis for the degree of bachelor in History and Geography (Bachelor Thesis). Universidad de Cuenca, Cuenca.

Certeau, M. de. (1984). The practice of everyday life. (S. Rendall, Trans.). Berkeley: University of California Press.

Chacon, J., Espinoza, L., Achig, L., Martinez, R., Palomeque, S., Vintimilla, M. A., Carrasco, A. (1982). Ensayos sobre historia regional: la región centro sur. (C. Cordero, Ed.). Cuenca, Ecuador: Instituto de Investigaciones Sociales de la Universidad de Cuenca.

Chacón Zhapán, J. (1990). Historia del corregimiento de Cuenca (1557 - 1777). Banco Central del Ecuador.

Dezeuze, A. (2008). Assemblage, Bricolage, and the Practice of Everyday Life. Art Journal, 67(1), 31-37.

Espinoza, L. (Ed.). (1989). La sociedad azuayo-cañari: pasado y presente (Vol. 1). Quito: Ed. El Conejo u.a.

Jaramillo, D., Martínez, J., Salazar, E., Abad, A., \& Aguilar, F. (2004). Cuenca: Santa Ana de las Aguas. Quito: Ed. Libri Mundi.

Levi-Strauss, C. (1962). Savage Mind. (J. Pitt-Rivers \& E. Gellner, Eds.) (1994 (Reprint 2004)). Oxford: Oxford University Press.

Mcfarlane, C. (2011). The City as Assemblage: Dwelling and Urban Space. Environment and Planning D: Society and Space, 29(4), 649-671.

Ordoñez, L. (1935). Cuenca i sus alrededores [Cuenca and its vecinity]. Cuenca, Ecuador: Archivo Fotográfico Banco Central del Ecuador [Ecuadorian Central Bank's photographic archive].

Palomeque, S. (1990). Cuenca en el siglo XIX: la articulación de una región (Vol. 2). Editorial Abya Yala. Retrieved from

Poloni-Simard, J. (2006). El mosaico indígena: movilidad, estratificación social y mestizaje en el corregimiento de Cuenca ( Ecuador) del siglo XVI al XVIII. Editorial Abya Yala.

Real, P. del. (2008). Slums Do Stink: Artists,Bricolage, and Our Need for Doses of "Real" Life. Art Journal, 67(1), 82-99.

Rowe, C., \& Koetter, F. (1978). Collage city. Cambridge, Mass.: MIT Press.

Saunders, J. V. D. (1961). Man-land relations in Ecuador. Rural Sociology, 26(1), 57-69.

Shane, D. G. (2005). Recombinant urbanism: conceptual modeling in architecture, urban design, and city theory. Chichester: Wiley-Academy.

Zouain, G. S. (2005). Integrated management of cultural heritage: Heritage conservation and use in the light of economic theory,. Barcelona. 


\section{FUENTES ELECTRONICAS}

Instituto Nacional de Estadísticas y Censos INEC. (2016). Encuesta Nacional de Empleo, Desempleo y Subempleo. Indicadores Laborales [National survey of employment, unemployment and underemployment] (p. 52). Quito: INEC. Retrieved from http://www.ecuadorencifras.gob.ec/empleoseptiembre-201/ 